J. Dairy Sci. 95:1921-1929

http://dx.doi.org/10.3168/jds.2011-5065

(C) American Dairy Science Association ${ }^{\circledR}, 2012$.

\title{
Herd-level association between antimicrobial use and antimicrobial resistance in bovine mastitis Staphylococcus aureus isolates on Canadian dairy farms
}

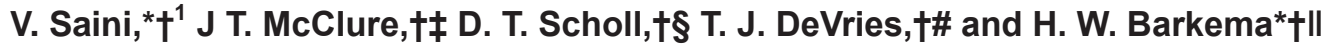 \\ *Department of Production Animal Health, University of Calgary, Calgary, Alberta, T2N 4N1, Canada \\ †Canadian Bovine Mastitis Research Network, C. P. 5000, St-Hyacinthe, Québec, J2S 7C6, Canada \\ ‡Department of Health Management, Atlantic Veterinary College, University of Prince Edward Island, Charlottetown, Prince Edward Island, \\ C1A 4P3, Canada \\ §Department of Pathology and Microbiology, Faculty of Veterinary Medicine, University of Montreal, Saint-Hyacinthe, Québec, J2S 7C6, Canada \\ \#Department of Animal and Poultry Science, University of Guelph, Kemptville Campus, Kemptville, Ontario, K0G 1J0, Canada \\ \|Department of Reproduction, Obstetrics and Herd Health, Ghent University, Merelbeke, Belgium
}

\section{ABSTRACT}

Surveillance of antimicrobial use and resistance is needed to manage antimicrobial resistance in bacteria. In this study, data were collected on antimicrobial use and resistance in Staphylococcus aureus $(\mathrm{n}=562)$, isolated from intramammary infections and (sub)clinical mastitis cases on 89 dairy farms in 4 regions of Canada [Alberta, Ontario, Québec, and the Maritime Provinces (Prince Edward Island, Nova Scotia, and New Brunswick)]. Dairy producers were asked to deposit empty drug containers into specially provided receptacles, and antimicrobial drug use rate was calculated to quantify antimicrobial use. Minimum inhibitory concentrations were determined using the Sensititer bovine mastitis plate system (TREK Diagnostic Systems Inc., Cleveland, $\mathrm{OH})$, containing antimicrobials commonly used for mastitis treatment and control. Multivariable logistic regression models were built to determine herd-level risk factors of penicillin, ampicillin, pirlimycin, penicillin-novobiocin combination, tetracycline and sulfadimethoxine resistance in Staph. aureus isolates. Intramammary administration of the penicillin-novobiocin combination for dry cow therapy was associated with penicillin and ampicillin resistance [odds ratio (OR): 2.17 and 3.10, respectively]. Systemic administration of penicillin was associated with penicillin resistance (OR: 1.63). Intramammary administration of pirlimycin for lactating cow mastitis treatment was associated with pirlimycin resistance as well (OR: 2.07). Average herd parity was associated with ampicillin and tetracycline resistance (OR: 3.88 and 0.02, respectively). Average herd size was also associated with tetracycline resistance (OR: 1.02). Dairy herds in the Maritime region

Received October 19, 2011

Accepted December 14, 2011.

${ }^{1}$ Corresponding author: vsaini@ucalgary.ca had higher odds of penicillin and lower odds of ampicillin resistance than dairy herds in Québec (OR: 2.18 and 0.19 , respectively). Alberta dairy herds had lower odds of ampicillin and sulfadimethoxine resistance than dairy herds in Québec (OR: 0.04 and 0.08, respectively). Ontario dairy herds had lower odds of tetracycline and sulfadimethoxine resistance than dairy herds in Québec (OR: 0.05 and 0.33, respectively). Herd-level use of certain antimicrobials administered for mastitis treatment and control, such as intramammary penicillin and pirlimycin as well as systemically administered penicillin and florfenicol, was positively associated with antimicrobial resistance in bovine mastitis pathogens in the field conditions. Differences in antimicrobial resistance outcomes across 4 regions of Canada were observed.

Key words: antimicrobial resistance, antimicrobial use, mastitis, Staphylococcus aureus

\section{INTRODUCTION}

Antimicrobial use in humans and animals is considered a primary cause of antimicrobial resistance (AMR) in bacteria, which is a public health hazard (Levy and Marshall, 2004). Concern is growing about the use of antimicrobials in food-animal production systems and its potential role in creating reservoirs of AMR determinants that can be transferred from animal to human populations along the food chain (White and McDermott, 2001; Tikofsky et al., 2003). Dairy farms form an ideal environment in which bacteria are subjected to antimicrobial treatments, and the subsequent selection pressure might favor selection and dissemination of resistant strains (Acar and Moulin, 2006; Silbergeld et al., 2008). It is, therefore, important to identify and measure factors affecting antimicrobial use (AMU) and AMR in a dairy farm environment for both clinical and public health reasons. 
Mastitis is the primary reason for AMU in dairy cattle (Mitchell et al., 1998). A variety of mastitis pathogens, namely Staphylococcus aureus, Streptococcus species, Escherichia coli, Klebsiella species, and CNS are commonly isolated from bovine IMI (Piepers et al., 2007; Olde Riekerink et al., 2008). Staphylococcus aureus remains one of the most important causes of clinical mastitis, and the most frequently isolated pathogen in subclinical mastitis cases worldwide (Waage, 1997; Barkema et al., 1998; Roberson et al., 1998; Olde Riekerink et al., 2008; Sampimon et al., 2009). Antimicrobial therapy is the preferred approach for decreasing the incidence and duration of mastitis infection on a dairy farm (Erskine et al., 2002). Cephalosporins, penicillins, penicillin combinations, lincosamides, and macrolides are most commonly administered intramammarily either during the lactation or dry period for treatment and prevention of mastitis in dairy cattle (Saini et al., 2012). However, despite best possible antimicrobial treatments, bacteriological cure failures are common in Staph. aureus mastitis, and AMR is considered as one of the reasons for low cure rates (Barkema et al., 2006). Resistance to various antimicrobials is commonly seen in bovine Staph. aureus mastitis isolates. For example, prevalence of AMR has ranged from 7 to $63 \%$ for penicillin (Watts and Salmon, 1997; Güler et al., 2005), 0 to $12 \%$ for oxacillin [FINRES-Vet, 2007; V. Saini, J. T. McClure, D. Léger (PHAC, Guelph, Canada), G. P. Keefe (UPEI, Charlottetown, Canada), D. T. Scholl, D. W. Morck (University of Calgary, Canada), and H. W. Barkema, unpublished data], 0 to $93 \%$ for erythromycin (FINRES-Vet, 2007; Wang et al., 2008), 0 to $28 \%$ for tetracycline (Watts and Salmon, 1997; Güler et al., 2005 ), and 4.5 to $7.5 \%$ for sulfadimethoxine (Makovec and Ruegg, 2003; Sabour et al., 2004) across various studies. In general, $\beta$-lactamase-negative Staph. aureus strains have higher bacteriological cure rates than $\beta$-lactamase producing stains (Ziv and Storper, 1985; Sol et al., 2000).

A few studies have assessed an association between AMU and AMR in bovine mastitis pathogens with conflicting results (Tikofsky et al., 2003; Rajala-Schultz et al., 2004; Roesch et al., 2006; Pol and Ruegg, 2007). Tikofsky et al. (2003) compared antimicrobial susceptibility patterns of Staph. aureus in organic and conventional dairy herds in the United States and found that isolates from organic herds were significantly more susceptible. No such differences were found in a Swiss study when comparing antimicrobial susceptibility of Staph. aureus isolated from organic and conventional farms (Roesch et al., 2006). Pol and Ruegg (2007) collected information on herd-level AMU and antimicrobial susceptibility profiles of gram-positive mastitis pathogens including Staph. aureus on organic and conventional dairy farms; those researchers found associations between AMU for mastitis treatment and control and AMR for some antimicrobials. None of these studies modeled AMR in bovine mastitis pathogens by including $\mathrm{AMU}$ (quantity and route of administration) and other herd-level predictors [region, milk production, barn type, SCC, parity, and source of isolates (subclinical, clinical mastitis, or IMI), severity of mastitis (mild, moderate, or severe)] that could potentially affect the AMU-AMR association. In fact, convincing evidence is lacking that AMU for mastitis treatment and control is associated with AMR in bovine mastitis pathogens in a dairy farm environment (Hillerton and Berry, 2005). The objective of the present study was to determine the herd-level association between AMU and other herdlevel predictors, and AMR in Staph. aureus isolated from IMI and (sub)clinical bovine mastitis cases on Canadian dairy farms.

\section{MATERIALS AND METHODS}

\section{Dairy Cattle Herd Selection}

Data for this study originated from the National Cohort of Dairy Farms of the Canadian Bovine Mastitis Research Network, which consisted of 91 commercial dairy farms located in 4 regions across Canada [Alberta, Ontario, Québec, and the Maritime Provinces (Prince Edward Island, Nova Scotia, and New Brunswick)]. Herd selection criteria for the present study have been described by (Reyher et al., 2011). In short, dairy herds were selected to replicate the regional proportion of freestall systems to within 15 percentage points, and to be uniformly distributed among 3 strata of the most recent 12 -mo bulk-tank SCC average ( $\leq 150,000$ cells/ $\mathrm{mL},>150,000$ and $\leq 300,000$ cells $/ \mathrm{mL}$, and $>300,000$ cells $/ \mathrm{mL}$ ); herds with a schedule of 3 times milking per day, herds with less than $80 \%$ (or less than 15) Holstein lactating and dry cows at the time of enrollment, and organic dairy herds were excluded. Further, eligible dairy herds must have been participating in a DHI data collection program. Eligible dairy farms were identified and contacted by the regional center coordinators. Written consent to participate in the research cohort was obtained. Two dairy herds dropped out of the study at the very beginning, leaving 89 herds in the study. Sixtyone, 33,5 , and $1 \%$ of these dairy herds housed lactating cows in tie-stalls, freestalls, in a bedding-packed barn, and mixed barn type, respectively. An investigator and technicians in each coordinating center were responsible for data collection activities related to the remaining farms located in that center's area. 


\section{Antimicrobial Use Data Collection Methodology}

Antimicrobial use data collection has been described by Saini et al. (2012). In short, AMU data were collected from February 2007 until December 2008. Fortyliter receptacles were placed on participating farms for collecting data for AMU. These receptacles were placed near the drug storage area, in the milking parlor, or any place near where the treatments were normally given. Producers, farm workers, and other farm personnel were instructed to deposit the empty containers of all drugs used by them or the veterinarian for treatment of calves, heifers, and adult cows (dry cows and lactating cows) into these receptacles. Farms were visited at least once per month. The research technicians emptied the receptacles, counted the empty drug containers, and recorded the inventory in the drug tally sheets at the dairy farm.

Antimicrobial use data were quantified in units of animal defined daily doses (ADD). The ADD (g/d) was defined as the average daily on-label dosage multiplied by the approximate weight of an adult dairy cow (BW $=600 \mathrm{~kg}$; Jensen et al., 2004) and was based on the Canadian compendium of veterinary products (CVP). Further, antimicrobial drug use rate (ADUR) was defined as number of ADD used on a farm per 1,000 cows (milking and dry) per day. Antimicrobial drug use rate was the herd-level estimate of AMU (Table 1).

\section{Sampling and Bacterial Culturing}

Sampling and bacterial culturing of isolates has been described elsewhere (Reyher et al., 2011). In short, 3 different sets of milk samples were collected. The first set included milk samples from clinical mastitis cases. All producer-diagnosed clinical mastitis cases were sampled and then resampled twice at 2-wk intervals. These samples included only quarter-milk samples.

The second set was from milk samples from nonclinical lactating cows; a subsample of 15 lactating cows (5 most recently fresh and 10 randomly chosen cows) was selected per farm. They were aseptically sampled and resampled once every $3 \mathrm{wk}$ for a total of 3 samplings in the winter of 2007; another subsample of 15 lactating cows was sampled once per week for 7 wk in the summer of 2007.

The third set of milk samples was collected from another selected group of 15 cows that were expected to remain in the herd until at least $2 \mathrm{wk}$ after calving. A subsample was aseptically sampled before dry-off and after calving in 2007 and this continued in 2008 as well. Quarter and composite milk samples were collected. Samples were frozen at $-20^{\circ} \mathrm{C}$ and shipped to the regional Canadian Bovine Mastitis Research Network

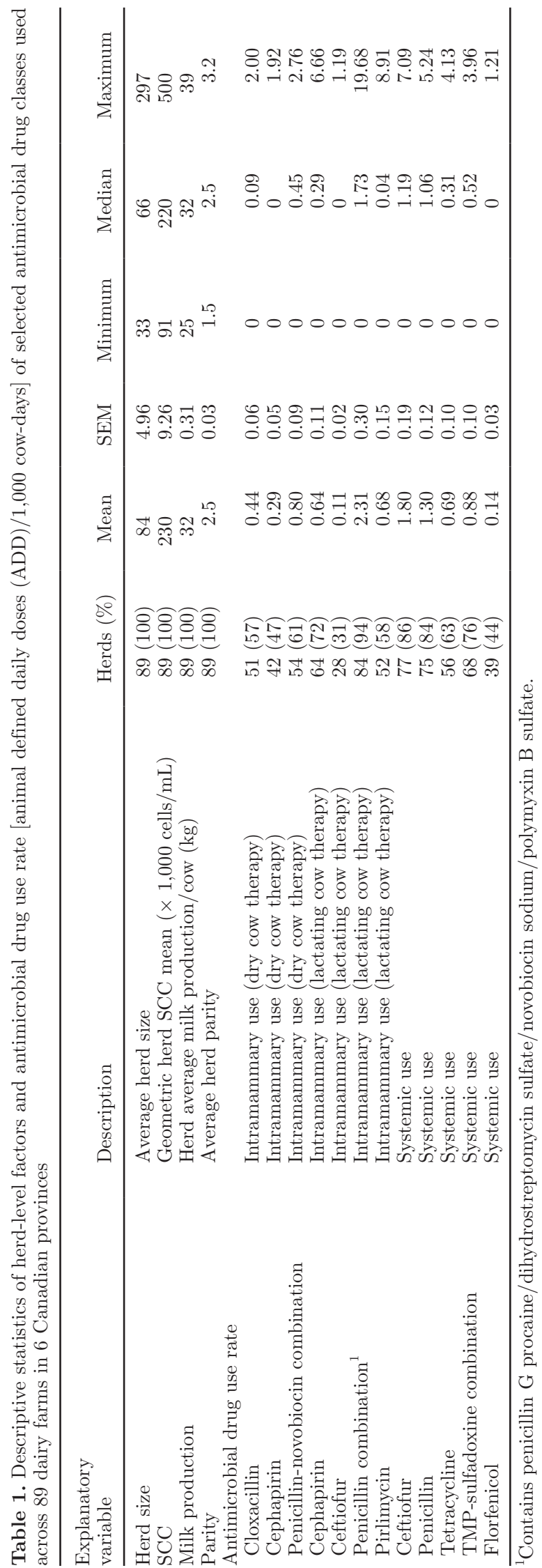

Journal of Dairy Science Vol. 95 No. 4, 2012 
laboratory where bacterial culturing and identification of the milk samples was done as per National Mastitis Council guidelines (Hogan et al., 1999).

Because multiple isolates could be coming from a single cow, it was decided to include only 1 isolate per quarter. Clinical mastitis was defined as an inflammation of the udder leading to occurrence of flakes, clots, or other gross alterations in milk. Subclinical mastitis was defined as SCC $>200,000$ cells/mL from a cow without clinical signs of mastitis, whereas IMI was defined as a culture-positive sample (Reyher et al., 2011).

\section{MIC Determination}

Antimicrobial susceptibility testing for these Staph. aureus isolates has been described elsewhere [V. Saini, J. T. McClure, D. Léger (PHAC, Guelph, Canada), G. P. Keefe (UPEI, Charlottetown, Canada), D. T. Scholl, D. W. Morck (University of Calgary, Canada), and H. W. Barkema, unpublished data]. Minimum inhibitory concentrations of these isolates were determined using the Sensititer microdilution system (TREK Diagnostic Systems Inc., Cleveland, OH). Sensititer Mastitis plate format CMV1AMAF containing ampicillin, ceftiofur, cephalothin, erythromycin, oxacillin, penicillin, penicillin-novobiocin combination, pirlimycin, sulfadimethoxine, and tetracycline was used.

\section{Statistical Analyses}

Antimicrobial use data were entered into a customized database (Microsoft Office Access 2006; Microsoft Corp., Redmond, WA). A random sample of the drug tally sheets $(25 \%)$ was checked manually to detect errors in data entry. Data analyses were performed using Intercooled Stata 11.1 (Intercooled Stata for Macintosh, version 11.1; Stata Corp., College Station, TX).

Minimum inhibitory concentration was defined as the lowest concentration of an antimicrobial that inhibited any visible growth of an isolate. In case of an antimicrobial combination such as penicillin-novobiocin, the MIC of the first agent (penicillin) was reported as the MIC for the combination. The isolates were also categorized as susceptible, intermediate, or resistant on the basis of Committee of Laboratory Standards Institute-based MIC breakpoints (CLSI, 2008). Intermediate isolates were combined with resistant isolates for the sake of statistical analysis. For analytical purposes, the unit of analysis was resistance at the herd level (0: number of resistant isolates at a farm $=0$; and 1: number of resistant isolates at a farm $\geq 1$ ). Herd-level prevalence percentage of AMR was defined as the percentage of total number of herds with AMR isolates divided by total number of herds sampled.
All independent variables (AMU and other herd-level factors such as region, herd average milk production, barn type, herd average SCC, herd average parity, average herd size, and number of isolates sampled at a farm) were screened based on descriptive statistics (means, variances, percentiles for continuous variables, and frequency tabulations for categorical variables) so as to exclude variables that had little variability (Dohoo et al., 2009). Subsequently, these independent variables were screened for univariate associations using the likelihood ratio test statistic (Hosmer and Lemeshow, 2000). Variables significant at $P \leq 0.25$ were eligible for inclusion in the multivariable logistic regression models. Using backward elimination, variables were retained in the model only if significant at $P \leq$ 0.05 unless exclusion resulted in a significant change in deviance. Thereafter, any variables not selected for the original multivariable model were added back into the model to identify variables that were not significantly associated with the herd-level outcome, but made an important contribution in the presence of other variables (distorter variables). Barn type, region, average herd size, and average herd parity were considered a priori as potential confounders. Variables including average herd SCC, herd average milk production per cow, average herd size, and average herd parity were centered at their respective lowest values for sensible interpretation of the intercept value.

The assumption of linearity in the logit of herd-level AMR outcome for continuous variables was evaluated graphically using lowess smoother scatter plots (Dohoo et al., 2009) and then by using fractional polynomials command in Intercooled Stata 11.1. Two-way interaction terms were added one at a time to the main effects model and retained at $P \leq 0.05$ unless exclusion resulted in a significant change in deviance. Robust standard errors were used to control for clustering of farms within regions. In case of nominal variables such as region, the baseline/referent level was selected as the one with sufficiently large sample size (Dohoo et al., 2009).

Multivariable logistic regression models were built for the following AMR outcomes: penicillin, ampicillin, pirlimycin, penicillin-novobiocin combination, tetracycline, and sulfadimethoxine. No models could be built for oxacillin and cephalothin due to absence of resistance, and for ceftiofur and erythromycin due to low prevalence of herd-level resistance.

\section{RESULTS}

\section{Antimicrobial Resistance Proportions}

Minimum inhibitory concentration values were determined for 562 isolates that came from 562 quarters 
Table 2. Descriptive statistics of herd-level antimicrobial resistance outcomes in Staphylococcus aureus $(\mathrm{n}=562)$ isolated from IMI, subclinical mastitis, and clinical mastitis cases in dairy cattle on 79 dairy farms across 6 provinces in Canada

\begin{tabular}{|c|c|c|c|c|c|c|c|}
\hline $\begin{array}{l}\text { Resistance } \\
\text { outcome }\end{array}$ & $\begin{array}{c}\text { Herds }^{1} \\
(\%)\end{array}$ & Isolates $^{2}$ & Mean $^{3}$ & SEM & Minimum & Median & Maximum \\
\hline Penicillin & $28(35.4)$ & 49 & 0.62 & 0.15 & 0 & 0 & 9 \\
\hline Oxacillin & 0 & 0 & - & - & - & - & - \\
\hline Pirlimycin & $6(7.5)$ & 14 & 0.17 & 0.11 & 0 & 0 & 9 \\
\hline Penicillin-novobiocin & $6(7.5)$ & 6 & 0.07 & 0.02 & 0 & 0 & 1 \\
\hline Ceftiofur & $2(2.5)$ & 2 & 0.02 & 0.01 & 0 & 0 & 1 \\
\hline Sulfadimethoxine & $28(35.4)$ & 38 & 0.48 & 0.08 & 0 & 0 & 3 \\
\hline
\end{tabular}

${ }^{1}$ Number of herds with antimicrobial-resistant Staphylococcus aureus isolates.

${ }^{2}$ Number of antimicrobial-resistant Staphylococcus aureus isolates.

${ }^{3}$ Average number of antimicrobial-resistant Staphylococcus aureus isolates per farm.

of 462 cows on 79 dairy farms. The total number of isolates resistant to 1 or more antimicrobials was 114 or a prevalence of $20.4 \%$ (95\% CI: 17.2 to $24.0 \%$ ). The total number of isolates resistant to an antimicrobial ranged from 0 to 9 per farm. Herd-level AMR prevalence proportions ranged from $0 \%$ for cephalothin and oxacillin to $35.4 \%$ for penicillin and sulfadimethoxine (Table 2).

\section{Multivariable Analyses}

The odds for herds having at least 1 penicillin-resistant Staph. aureus isolate increased with an increasing use of the penicillin-novobiocin combination administered for dry cow therapy and systemically adminis- tered penicillin (Table 3). Dairy herds in the Maritime region had significantly higher odds of having at least 1 penicillin-resistant Staph. aureus isolate than did dairy herds in Québec.

The odds of ampicillin resistance at the herd level increased significantly with the increased use of the penicillin-novobiocin combination administered for dry cow therapy and systemically administered florfenicol (Table 3). The odds of ampicillin resistance also increased significantly with an increase in average herd parity. Dairy herds in Alberta and Maritime regions had significantly lower odds of ampicillin resistance than did dairy herds in Québec.

The odds of pirlimycin resistance at the herd level also increased significantly with increase in the use

Table 3. Final logistic regression models depicting herd-level association between antimicrobial use and antimicrobial resistance to penicillin and ampicillin in Staphylococcus aureus $(\mathrm{n}=562)$ isolated from bovine mastitis cases on 79 dairy farms in 6 Canadian provinces

\begin{tabular}{|c|c|c|c|c|c|}
\hline $\begin{array}{l}\text { Resistance } \\
\text { outcome }\end{array}$ & Variable & $\begin{array}{l}\text { Odds } \\
\text { ratio }\end{array}$ & $\begin{array}{c}\text { Robust } \\
\text { SE }\end{array}$ & $P$-value & $95 \% \mathrm{CI}$ \\
\hline \multirow[t]{7}{*}{ Penicillin } & Penicillin-novobiocin use (dry cow therapy) & 2.17 & 0.56 & 0.003 & 1.30 to 3.61 \\
\hline & Penicillin use (systemic) & 1.63 & 0.26 & 0.003 & 1.18 to 2.25 \\
\hline & Average herd parity & 1.76 & 1.85 & 0.58 & 0.22 to 13.80 \\
\hline & Barn type (0: freestall, 1: tie-stall) & 2.29 & 2.00 & 0.34 & 0.41 to 12.72 \\
\hline & Region & & & & \\
\hline & Alberta & 0.29 & 0.19 & 0.058 & 0.08 to 1.04 \\
\hline & Maritimes & 2.18 & 0.39 & $<0.01$ & 1.53 to 3.09 \\
\hline \multirow[t]{6}{*}{ Ampicillin } & Penicillin-novobiocin use (dry cow therapy) & 3.10 & 0.60 & $<0.01$ & 2.21 to 4.55 \\
\hline & Penicillin use (systemic) & 1.96 & 0.74 & 0.07 & 0.93 to 4.13 \\
\hline & Florfenicol use (systemic) & 20.86 & 29.07 & 0.02 & 1.36 to 320.19 \\
\hline & Average herd size & 1.003 & 0.01 & 0.85 & 0.96 to 1.04 \\
\hline & Alberta & 0.04 & 0.06 & 0.04 & 0.002 to 0.86 \\
\hline & Maritimes & 0.19 & 0.08 & $<0.01$ & 0.08 to 0.46 \\
\hline
\end{tabular}


Table 4. Final logistic regression models depicting herd-level association between antimicrobial use and antimicrobial resistance to pirlimycin, penicillin-novobiocin combination, tetracycline, and sulfadimethoxine in Staphylococcus aureus $(\mathrm{n}=562)$ isolated from bovine mastitis cases on 79 dairy farms in 6 Canadian provinces

\begin{tabular}{|c|c|c|c|c|c|}
\hline $\begin{array}{l}\text { Resistance } \\
\text { outcome }\end{array}$ & Variable & $\begin{array}{l}\text { Odds } \\
\text { ratio }\end{array}$ & $\begin{array}{l}\text { Robust } \\
\text { SE }\end{array}$ & $P$-value & $95 \% \mathrm{CI}$ \\
\hline \multirow[t]{9}{*}{ Pirlimycin } & Pirlimycin use (lactating cow therapy) & 2.07 & 0.42 & $<0.01$ & 1.38 to 3.09 \\
\hline & Average herd size & 1.00 & 0.01 & 0.65 & 0.97 to 1.04 \\
\hline & Average herd parity & 0.34 & 0.57 & 0.52 & 0.01 to 9.03 \\
\hline & Barn type (0: freestall, 1: tie-stall) & 4.15 & 9.72 & 0.54 & 0.04 to 407.87 \\
\hline & Region & & & & \\
\hline & Québec (baseline) & 1.00 & & & \\
\hline & Ontario & 0.91 & 0.43 & 0.85 & 0.36 to 2.31 \\
\hline & Alberta & \multicolumn{4}{|c|}{ Omitted due to absence of resistance } \\
\hline & Maritimes & 1.79 & 2.27 & 0.64 & 0.14 to 21.69 \\
\hline \multirow[t]{10}{*}{ Penicillin-novobiocin combination } & Penicillin-novobiocin use (dry cow therapy) & 1.23 & 0.56 & 0.65 & 0.49 to 3.04 \\
\hline & Florfenicol use (systemic) & 34.56 & 92.95 & 0.18 & 0.17 to 6,726 \\
\hline & Average herd size & 1.00 & 0.01 & 0.74 & 0.96 to 1.04 \\
\hline & Average herd parity & 12.63 & 28.56 & 0.26 & 0.15 to 1,060 \\
\hline & Barn type (0: freestall, 1: tie-stall) & 1.25 & 2.48 & 0.90 & 0.02 to 60.52 \\
\hline & Region & & & & \\
\hline & Québec (baseline) & 1.00 & & & \\
\hline & Ontario & 14.14 & 20.59 & 0.06 & 0.81 to 245.42 \\
\hline & Alberta & \multicolumn{4}{|c|}{ Omitted due to absence of resistance } \\
\hline & Maritimes & 6.85 & 9.09 & 0.14 & 0.50 to 92.21 \\
\hline \multirow[t]{9}{*}{ Tetracycline } & Tetracycline use (systemic) & 1.13 & 1.11 & 0.89 & 0.16 to 7.73 \\
\hline & Average herd size & 1.02 & 0.008 & 0.005 & 1.007 to 1.03 \\
\hline & Average herd parity & 0.02 & 0.02 & $<0.01$ & 0.004 to 0.13 \\
\hline & Barn type (0: freestall, 1: tie-stall) & 0.08 & 0.19 & 0.28 & 0.008 to 7.92 \\
\hline & Region & & & & \\
\hline & Québec (baseline) & 1.00 & & & \\
\hline & Ontario & 0.05 & 0.029 & $<0.01$ & 0.018 to 0.15 \\
\hline & Alberta & \multicolumn{4}{|c|}{ Omitted due to absence of resistance } \\
\hline & Maritimes & 0.37 & 0.41 & 0.37 & 0.04 to 3.27 \\
\hline \multirow[t]{9}{*}{ Sulfadimethoxine } & TMPS $^{1}$ use (systemic) & 0.83 & 0.29 & 0.60 & 0.41 to 1.66 \\
\hline & Average herd size & 0.99 & 0.006 & 0.99 & 0.98 to 1.01 \\
\hline & Average herd parity & 1.27 & 1.48 & 0.83 & 0.12 to 12.55 \\
\hline & Barn type (0: freestall, 1: tie-stall) & 1.05 & 1.35 & 0.96 & 0.08 to 13.02 \\
\hline & Region & & & & \\
\hline & Québec (baseline) & 1.00 & & & \\
\hline & Ontario & 0.33 & 0.07 & $<0.01$ & 0.22 to 0.51 \\
\hline & Alberta & 0.08 & 0.06 & $<0.01$ & 0.01 to 0.40 \\
\hline & Maritimes & 0.40 & 0.24 & 0.13 & 0.12 to 1.34 \\
\hline
\end{tabular}

${ }^{1}$ Trimethoprim-sulfadoxine combination.

of pirlimycin administered for lactating cow mastitis treatment (Table 4). The odds of tetracycline resistance significantly decreased with an increase in herd average parity. The odds of tetracycline resistance increased significantly with an increase in average herd size. Dairy herds in Ontario had significantly lower odds of tetracycline resistance than did dairy herds in Québec. Dairy herds in Ontario and Alberta had significantly lower odds of sulfadimethoxine resistance than did dairy herds in Québec. No statistically significant interactions between explanatory variables were found.

\section{DISCUSSION}

The present study evaluated the effect of herd-level AMU on herd AMR profile patterns in bovine mastitis
Staph. aureus isolates. The study accounted for potential differences in AMU and antimicrobial susceptibility due to geographical and epidemiological differences. This is the first time that a Canada-wide prospective study has been undertaken to quantify on-farm AMU and AMR profile patterns and to determine an association between the 2 for bovine mastitis Staph. aureus pathogens.

Antimicrobial susceptibility testing was done using the Sensititer MIC system. The Sensititer MIC and Kirby-Bauer disk diffusion test methods have recently been validated for common bovine mastitis pathogens, and were found to have a moderate-to-high diagnostic accuracy and very good essential and categorical agreement for most udder pathogen-antimicrobial combinations (Saini et al., 2011). In general, prevalence of 
AMR was low in our Canadian bovine mastitis Staph. aureus isolates. Selection, emergence, and propagation of resistant bacterial populations require a) repeated exposure to an antimicrobial, b) access of the bacteria to a large resistance gene pool in a multi-bacterial environment, and c) presence of mobile genetic elements (Schwarz and Chaslus-Dancla, 2001). The environment inside the udder is virtually sterile as compared with the gastrointestinal tract where no indigenous bacterial flora is present (Werckenthin et al., 2001), and most IMI usually contain a single pathogen, thus limiting its exposure to resistant gene pools. Commonly used full-dose, short-term treatment regimens are unlikely to promote dissemination of resistance determinants in an udder environment (WHO, 1997) and could be a potential reason for lower prevalence of AMR in bovine mastitis pathogens.

Cross-resistance, potential co-selection and direct effects of AMU on AMR were observed in the present study. Direct effect means that AMU selects for AMR to the same antimicrobial (e.g., systemically administered penicillin selected for penicillin resistance in Staph. aureus isolates). Cross-resistance is observed when AMU selects for resistance to all antimicrobials in the same class (e.g., sulfonamides), some antimicrobials in a class (e.g., aminoglycosides), or antimicrobials belonging to different classes (e.g., resistance to macrolides, lincosamides, and B streptogramins) due to a single biochemical mechanism such as $\beta$-lactamase production, target overlapping, or unspecified drug efflux (Guardabassi and Courvalin, 2006). In this study, systemically administered penicillin selected for ampicillin resistance. Potential co-selection is observed when AMU selects for resistance to an antimicrobial of a different class due to coexistence of genes or mutations in the same strain. In this study, systemically administered florfenicol use was associated with ampicillin resistance. These results indicate that use of some antimicrobials is positively associated with AMR in bovine mastitis pathogens in field conditions.

Route of administration of an antimicrobial could potentially affect AMR in udder pathogens. For an antimicrobial to be effective, it must reach the site of infection in an effective concentration. The bovine udder is rich in blood supply. However, the rate of passage of an antimicrobial into milk after parentral administration depends upon the degree of lipid solubility and extent of plasma protein binding (Baggot, 2006). In general, only the lipid-soluble, non-ionized, and plasma protein unbound fraction of an antimicrobial can penetrate the blood-milk barrier to enter into milk and diffuse into transcellular fluid. Penicillins are predominantly ionized in plasma, are less lipid soluble, and cross biological membranes poorly; the concentration in milk is about one-fifth of that in the serum (Prescott, 2006). It is, therefore, quite likely, that subtherapeutic concentrations of penicillin achieved in the udder upon systemic administration may lead to the selection of penicillin and ampicillin resistant Staph. aureus strains.

It has long been speculated that administration of antimicrobials in dry cow therapy is associated with emergence of resistance in bovine mastitis pathogens (Østerås et al., 1999). The present study results provide support for that hypothesis. Pol and Ruegg (2007) also found a positive association between AMU and AMR in Staph. aureus isolates in the cases of penicillin and ampicillin, and a positive correlation between pirlimycin use and MIC in their study (Pol and Ruegg, 2007). In the present study, intramammary administration of the penicillin-novobiocin combination for dry cow treatment was associated positively with penicillin and ampicillin resistance. However, no associations were observed for cloxacillin, cephapirin, ceftiofur, and pirlimycin administered intramammarily for dry cow and lactating cow therapy. Interestingly, systemic administration of florfenicol was positively associated with ampicillin resistance. This is surprising because florfenicol is not known to induce $\beta$-lactamase production in Staph. aureus isolates. Therefore, either this is a spurious association or indicative of resistance mechanisms such as co-selection that are yet to be identified in Staph. aureus isolates.

In general, AMR tended to be associated with average herd parity and barn type; for example, the odds of penicillin and ampicillin resistance at a farm increased with an increase in average herd parity. Similar observations were made for CNS isolated from milk samples obtained from primiparous and multiparous cows (Sol et al., 2000; Rajala-Schultz et al., 2004). An increase in parity indicates an increase in age and, therefore, increased exposure to antimicrobials and mastitis pathogens. Age or BW could also influence relative systemic availability of an antimicrobial that could potentially affect AMR as well. Similar observations have been made in calves (Marshall and Palmer, 1980). Further, except for tetracycline, prevalence of AMR in Staph. aureus tended to be higher in tie-stall than freestall barns. It is quite likely, that barn type is a surrogate for management practices that potentially affect the AMU-AMR association in bovine mastitis pathogens. Incidence of IMI and (sub)clinical mastitis is the primary reason for AMU on a dairy farm. We, thus, recommend that information about management factors affecting the incidence of IMI and (sub)clinical mastitis on a dairy farm such as nutrition, milk production, leaking of milk, breed of cows, post-milking teat disinfection, housing, hygienic condition of cubicles and cows, and milking procedures (Barkema et al., 1999) 
should be collected in studies investigating risk factors of AMR. Regional differences in AMR prevalence were also observed. Different subpopulations of bacteria with varying antimicrobial susceptibilities exist in different regions (Erskine et al., 2003; Kirk et al., 2005). A region may be a surrogate for management-related differences due to environment, geography, weather, and resources availability that might affect AMR in bacteria.

The present study was a point-in-time snapshot of AMR in bovine mastitis pathogens and did not reflect temporal changes. The unit of analysis and concern in this AMU-AMR association study was the farm. Antimicrobial resistance is potentially a herd-level phenomenon, as farm ecosystems provide an ideal environment for emergence, amplification, and dissemination of resistant bacteria/determinants (Acar and Moulin, 2006). Second, data were collected on the herd-level use of antimicrobials; with individual cow-level AMU data being unavailable, it would be a fallacy to make inferences from this study at an individual cow level. Dairy herds in this study were not randomly selected. However, these herds were representative of their respective dairy herd populations in Canada (Reyher et al., 2011). Results of the present study can, therefore, be generalized to similar dairy farm populations across Canada.

\section{CONCLUSIONS}

Herd-level use of the penicillin-novobiocin combination administered intramammarily for dry cow therapy, and systemically administered penicillin was positively associated with penicillin resistance in Staph. aureus isolated from IMI and (sub)clinical bovine mastitis cases on Canadian dairy farms. Ampicillin resistance was associated with the use of systemically administered florfenicol. Intramammary administration of pirlimycin for clinical mastitis treatment was also associated with pirlimycin resistance. Average herd parity was associated with AMR to ampicillin and tetracycline. Differences existed in AMR to certain antimicrobials across 4 regions that could not be solely explained by AMU data. Data on management practices affecting the ecology of AMR in bovine mastitis pathogens should also be collected in future studies.

\section{ACKNOWLEDGMENTS}

The authors thank technicians Adele Veinot, Andrea Wasko, Anke Wellen, Francois Dubois, Meliza Morris, Mike MacLean, Natasha Robinson, and Theresa Andrews (all from Canadian Bovine Mastitis Research Network, St-Hyacinthe, QC, Canada) for collection of drug tally sheets, Vicky Stagg (University of Calgary,
Calgary, AB, Canada) for statistical programming, and Jean-Philippe Roy, Luc DesCôteaux, Ian Dohoo, Greg Keefe, and Kristen Reyher (all from Canadian Bovine Mastitis Research Network, St-Hyacinthe, QC, Canada) for coordination of the National Dairy Farm Cohort regional centers. This research was financed by the Natural Science and Engineering Research Council of Canada (Ottawa, ON, Canada), Alberta Milk (Edmonton, AB, Canada), Dairy Farmers of New Brunswick, Nova Scotia, Ontario and Prince Edward Island, Novalait Inc. (Quebec, QC, Canada), Dairy Farmers of Canada (Ottawa, ON, Canada), Canadian Dairy Network (Guelph, ON, Canada), Agriculture and AgriFood Canada (Ottawa, ON, Canada), Public Health Agency of Canada (Ottawa, ON, Canada), Technology PEI Inc. (Charlottetown, PEI, Canada), Université de Montréal (Montréal, QC, Canada), and University of Prince Edward Island (Charlottetown, PEI, Canada), through the Canadian Bovine Mastitis Research Network.

\section{REFERENCES}

Acar, J. F., and G. Moulin. 2006. Antimicrobial resistance at farm level. Rev. Sci. Tech. 25:775-792.

Baggot, J. D. 2006. Principles of antimicrobial drug bioavailability and disposition. Page 65 in Antimicrobial Therapy in Veterinary Medicine. S. Giguère, ed. Blackwell Publishing, Ames, IA.

Barkema, H. W., Y. H. Schukken, T. J. G. M. Lam, M. L. Beiboer, H. Wilmink, G. Benedictus, and A. Brand. 1998. Incidence of clinical mastitis in dairy herds grouped in three categories by bulk milk somatic cell counts. J. Dairy Sci. 81:411-419.

Barkema, H. W., Y. H. Schukken, T. J. Lam, M. L. Beiboer, G. Benedictus, and A. Brand. 1999. Management practices associated with the incidence rate of clinical mastitis. J. Dairy Sci. 82:1643-1654.

Barkema, H. W., Y. H. Schukken, and R. N. Zadoks. 2006. Invited review: The role of cow, pathogen, and treatment regimen in the therapeutic success of bovine Staphylococcus aureus mastitis. J. Dairy Sci. 89:1877-1895.

CLSI (Clinical and Laboratory Standards Institute). 2008. Performance Standards for Antimicrobial Disk and Dilution Susceptibility Tests for Bacteria Isolated from Animals. Approved Standard. 3rd ed. M31-A3: 65-72.

Dohoo, I. R., W. Martin, and H. Stryhn. 2009. Veterinary Epidemiologic Research. 2nd ed. VER Inc, Charlottetown, PEI, Canada.

Erskine, R. J., S. Wagner, and F. J. DeGraves. 2003. Mastitis therapy and pharmacology. Vet. Clin. North Am. Food Anim. Pract. 19:109-138.

Erskine, R. J., R. D. Walker, C. A. Bolin, P. C. Bartlett, and D. G. White. 2002. Trends in antibacterial susceptibility of mastitis pathogens during a seven-year period. J. Dairy Sci. 85:1111-1118.

FINRES-Vet. 2007. Finnish Veterinary Antimicrobial Resistance Monitoring and Consumption of Antimicrobial Agents, 2005-2006. Finnish Food Safety Authority Evira, Helsinki, Finland. Accessed Oct. 19, 2011. http://www.evira.fi/portal/en/evira/publications/? $\mathrm{a}=$ view\&productId $=178$.

Guardabassi, L., and P. Courvalin. 2006. Modes of antimicrobial action and mechanisms of bacterial resistance. Page 5 in Antimicrobial Resistance in Bacteria of Animal Origin. F. M. Aarestrup, ed. American Society of Microbiology, Washington, DC.

Güler, L., Ü. Ok, K. Gündüz, Y. Gülcü, and H. H. Hadimli. 2005. Antimicrobial susceptibility and coagulase gene typing of Staphylococcus aureus isolated from bovine clinical mastitis cases in Turkey. J. Dairy Sci. 88:3149-3154. 
Hillerton, J. E., and E. A. Berry. 2005. Treating mastitis in the cowA tradition or an archaism. J. Appl. Microbiol. 98:1250-1255.

Hogan, J. S., R. N. Gonzalez, R. Harmon, S. C. Nickerson, S. P. Oliver, J. W. Pankey, and K. L. Smith. 1999. Laboratory Handbook on Bovine Mastitis. National Mastitis Council Inc., Verona, WI.

Hosmer, D. W., and S. Lemeshow. 2000. Applied logistic regression. 2nd ed. John Wiley \& Sons Inc., Hoboken, NJ.

Jensen, V. F., E. Jacobsen, and F. Bager. 2004. Veterinary antimicrobial-usage statistics based on standardized measures of dosage. Prev. Vet. Med. 64:201-215.

Kirk, J. H., B. McCowan, E. R. Atwill, K. S. Glenn, G. E. Higginbotham, C. A. Collar, A. Castillo, B. A. Reed, N. G. Peterson, and J. S. Cullor. 2005. Association of minimum inhibitory concentration cluster patterns with dairy management practices for environmental bacteria isolated from bulk tank milk. J. Dairy Sci. 88:3710-3720.

Levy, S. B., and B. Marshall. 2004. Antibacterial resistance worldwide: Causes, challenges and responses. Nat. Med. 10:S122-S129.

Makovec, J. A., and P. L. Ruegg. 2003. Antimicrobial resistance of bacteria isolated from dairy cow milk samples submitted for bacterial culture: 8,905 samples (1994-2001). J. Am. Vet. Med. Assoc. 222:1582-1589.

Marshall, A. B., and G. H. Palmer. 1980. Injection sites and drug bioavailability. Page 54 in Trends in Veterinary Pharmacology and Toxicology. A. S. J. P. A. M Van Miert ed. Elsevier Publishing Company, Amsterdam, the Netherlands.

Mitchell, J. M., M. W. Griffiths, S. A. McEwen, W. B. McNab, and A. J. Yee. 1998. Antimicrobial drug residues in milk and meat: Causes, concerns, prevalence, regulations, tests, and test performance. J. Food Prot. 61:742-756.

Olde Riekerink, R. G. M., H. W. Barkema, D. F. Kelton, and D. T. Scholl. 2008. Incidence rate of clinical mastitis on Canadian dairy farms. J. Dairy Sci. 91:1366-1377.

Østerås, O., S. W. Martin, and V. L. Edge. 1999. Possible risk factors associated with penicillin-resistant strains of Staphylococcus aureus from bovine subclinical mastitis in early lactation. J. Dairy Sci. 82:927-938.

Piepers, S., L. De Meulemeester, A. de Kruif, G. Opsomer, H. W. Barkema, and S. De Vliegher. 2007. Prevalence and distribution of mastitis pathogens in subclinically infected dairy cows in Flanders, Belgium. J. Dairy Res. 74:478-483.

Pol, M., and P. L. Ruegg. 2007. Relationship between antimicrobial drug usage and antimicrobial susceptibility of gram-positive mastitis pathogens. J. Dairy Sci. 90:262-273.

Prescott, F. J. 2006. Beta-lactam antibiotics: Penam penicillins. Page 127 in antimicrobial therapy in veterinary medicine. S. Giguère, ed. Blackwell Publishing, Ames, IA.

Rajala-Schultz, P. J., K. L. Smith, J. S. Hogan, and B. C. Love. 2004. Antimicrobial susceptibility of mastitis pathogens from first lactation and older cows. Vet. Microbiol. 102:33-42.

Reyher, K. K., S. Dufour, H. W. Barkema, L. Des Côteaux, T. J. Devries, I. R. Dohoo, G. P. Keefe, J.-P. Roy, and D. T. Scholl. 2011. The National Cohort of Dairy Farms - A data collection platform for mastitis research in Canada. J. Dairy Sci. 94:16161626.

Roberson, J. R., L. K. Fox, D. D. Hancock, J. M. Gay, and T. E. Besser. 1998. Sources of intramammary infections from Staphylococcus aureus in dairy heifers at first parturition. J. Dairy Sci. 81:687-693.
Roesch, M., V. Perreten, M. G. Doherr, W. Schaeren, M. Schällibaum, and J. W. Blum. 2006. Comparison of antibiotic resistance of udder pathogens in dairy cows kept on organic and on conventional farms. J. Dairy Sci. 89:989-997.

Sabour, P. M., J. J. Gill, D. Lepp, J. C. Pacan, R. Ahmed, R. Dingwell, and K. Leslie. 2004. Molecular typing and distribution of Staphylococcus aureus isolates in Eastern Canadian dairy herds. J. Clin. Microbiol. 42:3449-3455.

Saini, V., J. T. McClure, D. Léger, S. Dufour, A. G. Sheldon, D. T. Scholl, and H. W. Barkema. 2012. Antimicrobial use on Canadian dairy farms. J. Dairy Sci. 95:1209-1221. http://dx.doi. org/10.3168/jds.2011-4527.

Saini, V., R. G. M. Olde Riekerink, J. T. McClure, and H. W. Barkema. 2011. Diagnostic accuracy assessment of Sensititre and agar disk diffusion for determining antimicrobial resistance profiles of bovine clinical mastitis pathogens. J. Clin. Microbiol. 49:15681577.

Sampimon, O., H. W. Barkema, I. Berends, J. Sol, and T. Lam. 2009. Prevalence of intramammary infection in Dutch dairy herds. J. Dairy Res. 76:129-136.

Schwarz, S., and E. Chaslus-Dancla. 2001. Use of antimicrobials in veterinary medicine and mechanisms of resistance. Vet. Res. $32: 201-225$.

Silbergeld, E. K., J. Graham, and L. B. Price. 2008. Industrial food animal production, antimicrobial resistance, and human health. Annu. Rev. Public Health 29:151-169.

Sol, J., O. C. Sampimon, H. W. Barkema, and Y. H. Schukken. 2000. Factors associated with cure after therapy of clinical mastitis caused by Staphylococcus aureus. J. Dairy Sci. 83:278-284.

Tikofsky, L. L., J. W. Barlow, C. Santisteban, and Y. H. Schukken. 2003. A comparison of antimicrobial susceptibility patterns for Staphylococcus aureus in organic and conventional dairy herds. Microb. Drug Resist. 9:S39-S45.

Waage, S. 1997. Comparison of two regimens for the treatment of clinical bovine mastitis caused by bacteria sensitive to penicillin. Vet. Rec. 141:616-620.

Wang, Y., C.-M. Wu, L.-M. Lu, G.-W. N. Ren, X.-Y. Cao, and J.-Z. Shen. 2008. Macrolide-lincosamide-resistant phenotypes and genotypes of Staphylococcus aureus isolated from bovine clinical mastitis. Vet. Microbiol. 130:118-125.

Watts, J. L., and S. A. Salmon. 1997. Activity of selected antimicrobial agents against strains of Staphylococcus aureus isolated from bovine intramammary infections that produce $\beta$-lactamase. J. Dairy Sci. 80:788-791.

Werckenthin, C., M. Cardoso, J.-L. Martel, and S. Schwarz. 2001. Antimicrobial resistance in staphylococci from animals with particular reference to bovine Staphylococcus aureus, porcine Staphylococcus hyicus, and canine Staphylococcus intermedius. Vet. Res. 32:341-362.

White, D. G., and P. F. McDermott. 2001. Emergence and transfer of antibacterial resistance. J. Dairy Sci. 84:E151-E155.

WHO (World Health Organization). 1997. Pages 11-16 in Recommendations in WHO Proceedings: The Medical Impact of Antimicrobial use in Food Animals. WHO/EMC/ZOO/97.4, 1997. WHO, Geneva, Switzerland.

Ziv, G., and M. Storper. 1985. Intramuscular treatment of subclinical staphylococcal mastitis in lactating cows with penicillin G, methicillin and their esters. J. Vet. Pharmacol. Ther. 8:276-283. 